\title{
Pojęcie „nowej sakralności” w muzyce cerkiewnej
}

\author{
Rafał Dmitruk \\ Chrześcijańska Akademia Teologiczna, Wydział Teologiczny Polska \\ ORCID: 0000-0002-2745-9976 \\ rafaldmitruk1@gmail.com
}

rev. R. Dmitruk, The concept of the "new sacredness" in Orthodox music, Elpis, 23 2021: 137-140.

\begin{abstract}
The article is devoted to the concept of the „new sacredness” in Orthodox music. The „new sacredness” is a term that has appeared in this field for some time. The article will analyze all the sources of this term. Church singing is designed to help the believer during the divine service in a conversation with God. Orthodox music and its influence should create an appropriate atmosphere that brings a person closer to God. The conductor and the composer play a very important role in this program. They have a great responsibility, because their main task is to help believers reach God.

Streszczenie: Poniższy artykuł dotyczy pojęcia „nowej sakralności” w muzyce cerkiewnej. „Nowa sakralność” to termin który pojawił się od pewnego czasu w tej dziedzinie. W artykule zostaną przeanalizowane wszystkie źródła tego terminu. Śpiew cerkiewny ma za zadanie pomóc wiernemu w czasie nabożeństwa w rozmowie z Bogiem. Muzyka cerkiewna i jej oddziaływanie ma stworzyć odpowiedni klimat który zbliża człowieka do Boga. Bardzo ważną rolę w tym przekazie odgrywają dyrygent oraz kompozytor. To na nich spoczywa wielka odpowiedzialność ponieważ ich głównym zadaniem jest pomoc wiernemu w dotarciu do Boga.
\end{abstract}

Keywords: Orthodox music, church singing, history of Orthodox music, sacred, composer

Slowa kluczowe: muzyka cerkiewna, śpiew cerkiewny, historia muzyki cerkiewnej, sakralność, kompozytor

Muzyka cerkiewna jest nieodzownym elementem w kulturze prawosławnej, która koncentruje w sobie aspekty moralne i estetyczne. Ich celem jest realizacja wartości uniwersalnych, nasyconych duchowością i nadzieją. Śpiew cerkiewny jako integralna część kultury chrześcijańskiej (o której mówią Ojcowie Kościoła, naukowcy, teologowie, filozofowie) zajął również centralne miejsce i odzwierciedlenie w dziełach wielu kompozytorów.

Analiza literatury naukowej potwierdza, że teolodzy i fillozofowie jednomyślnie określają jaki cel ma osiągnąć muzyka cerkiewna. Twierdzą oni, że powinna przede wszystkim charakteryzować się wyraźną stałą duchowością i być napełniona modlitewnym charakterem. Taki pogląd prezentowali również badacze muzyki cerkiewnej przełomu XIX i XX w. (Wozniesienski, Nikolski, Razumowski, Gardner, Martinow).

Na początku XX wieku ks. Dymitr Allemanow powiedział: „muzyka jest wartością która przebudza, wychowuje i najbardziej wyraża uczucia i jest niezbędna w rycie nabożeństwa" (Allemanov, 1911, s. 111). Podobne poglądy wyraża M. Lossky, patrząc na muzykę cerkiewną z punktu widzenia filozofii religii: ,,muzyk, kompozytor lub wykonawca musi być oczywiście „teologiem” w sensie kultywowania „katolickości-powszechności” w świadomości Kościoła. Oznacza to, że nigdy nie może zapominać, że jego główną rolą jest służenie w nabożeństwie i unikanie „samochwały”. A to oznacza, że powinien nakładać na siebie pewną odpowiedzialność w służeniu ludowi Bożemu, i nie narzucać innym swoje indywidualne upodobania" (Martynov, 1994, s. 240).

Kwestia zagadnień eklezjologii muzyki sakralnej nie straciła swojego znaczenia we współczesności. Ks. Dymitr Bołgarski (słynny muzyk i naukowiec cerkiewny) widzi sens śpiewu cerkiewnego w jego powszechności. Śpiew według niego jest symfonią prawidłowego koordynowania duchowego wzrastania człowieka. Śpiew jest procesem uduchowiania i głównym językiem nabożeństwa. Nie jest z tego świata tak jak i Kościół nie pochodzi z tego świata (Bolgars'ki, 2021). Próba naukowego zrozumienia muzyki cerkiewnej trwa już od wielu stuleci. Dla jego kompleksowego zbadania istotna jest analiza prac nie tylko krytyków sztuki, ale także teologów i filozofów. Dla ustalenia kanonów muzyki liturgicznej tradycji prawosławnej ważne są dzieła Ojców Kościoła: Grzegorza Teologa, Bazylego Wielkiego, Andrzeja z Krety, Jana z Damaszku, Jana Chryzostoma, Klemensa Aleksandryjskiego i wielu innych. To oni pracowali nad udoskonaleniem i ujednoliceniem nabożeństw, wcielając poetyckie idee, myśli, obrazy oraz prawdy religijnie.

Pierwsze fundamentalne opracowania muzyki cerkiewnej pojawiły się $\mathrm{w}$ drugiej połowie XIX i na początku XX wieku. Wśród badaczy śpiewu cerkiewnego z tego okresu należy wspomnieć o studencie Kijowskiego Duchownego Seminarium Dymitrze Razumowskim, który zapoczątkował systematyczne naukowe rozumienie muzyki duchowej (Razumovskij, 1867, s. 136). W jego monografii możemy przeczytać między innymi o szeroko rozwiniętej historii śpiewu liturgicznego, systemu osmogłasia oraz wykonywania śpiewu cerkiewnego w starożytnej cerkwi. Podkreśla on szczególną rolę św. Jana z Damaszku w kształtowaniu chrześcijańskich tradycji śpiewu oraz szeroko wyjaśnia zasady wykonywania dawnych systemów śpiewu (neumatycznego, greckiego, demestwiennego, buł- 
garskiego, kijowskiego). Do grona specjalistów z dziedziny prawosławnej muzyki duchowej drugiej połowy XIX - początku XX wieku możemy zaliczyć ks. Dymitra Allemanowa: „Garomonizacja drewnieruskogo cerkownogo pienija”, „Cerkownyje łady i garmonizacja ich po teorii drewnich didaskałow wostocznogo osmogłasija", Wasilija Metałłowa: „Osmogłasije znamiennogo raspiewa po głasowym popiewkam”, Jurija Arnołda „Teorija drewnie-ruskogo cerkownogo i narodnogo pienija na osnowani awtienticzeskich traktatow i akusticzeskogo analiza". Analiza powyższych badań świadczy o dużym zainteresowaniu naukowców dziejami prawosławnej muzyki liturgicznej, starożytnych śpiewów w kontekście misterium nabożeństw.

Metodologię nauczania prawosławnej muzyki sakralnej pokazuje w swoich pracach badaczka L. Gustowa, która dzieli je na: historyczne, liturgiczne, soteriologiczne, hierotopiczne ${ }^{1}$ metody, podkreślając, że ten ostatni rodzaj jest kluczowym w kategorii pojęcia przestrzeni sakralnej (Gustova, 2011, s. 64-67). Na przełomie XX i XXI wieku widzimy duże zainteresowanie starożytnymi fundamentami śpiewu liturgicznego nie tylko w badaniach naukowych, ale również w twórczości kompozytorskiej. Należy również zauważyć, że potrzebę odrodzenia starożytnych śpiewów(które koncentrują w sobie modlitewność i kanoniczność prawosławia) w praktyce liturgicznej, podkreślają i wcielają słynni dyrygenci: D. Bołgarskij, O. Wasiliew, A. Grindenko, W. Mełnyk, metropolita Jonafan (Jeleckich) i inni. Na szczególną uwagę zasługuje postać metropolity Jonafana, który łączy tradycyjne utwory z „wymaganiami” sakralnymi współczesnych czasów. Opracował wiele utworów zapisanych na ponad 1600 stronach, które spełniają zarówno kryteria liturgiczne, jak i paraliturgiczne. W swoich utworach metropolita odwołuje się do kanonicznych starodawnych melodii, tym samym podtrzymuje odrodzenie starodawnych fundamentów liturgicznego śpiewu. Muzyka metropolity Jonafana wzbudza duże zainteresowanie nie tylko wśród środowisk cerkiewnych, ale również wśród świeckich chórów.

Dzisiaj do sakralności uczeni odnoszą się ze zrozumieniem. Poszerzają jego semantyczne pole, wychodząc poza praktykę liturgiczną, ekstrapolując je na zjawiska świeckie. Jednak większość badaczy rozpatruje pojęcie sakralności w kontekście chrześcijańskiej sztuki bezpośrednio związanej z cerkwią i nabożeństwem, gdzie w sakralnej przestrzeni i czasie ma miejsce spotkanie człowieka ze Stwórcą. Zarówno obecnie, jak i dawniej, głównym celem sztuki sakralnej jest komunikacja religijna. Estetyczne kryteria ulegają radykalnym zmianom, nabywając cech świeckiej sztuki, co daje podstawy do uznania tego procesu za sekularyzację. Jeśli jednak chodzi tu tylko o zmianę form sztuki, a nie treść, nie ma podstaw, aby uważać, że wy-

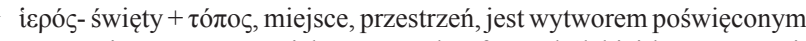
przestrzeni postrzeganym jako szczególna forma ludzkiej kreatywności, a także pokrewna dziedzina akademicka, w której bada się konkretne przykłady takiej twórczości. Jako dziedzina akademicka obejmuje dyscypliny: Historia sztuki, archeologia, antropologia kulturowa, etnologia i religioznawstwo, ale posiada przedmiot badań i własną metodologię. Koncepcja i termin zostały opracowane w 2002 roku przez Rosyjskiego historyka sztuki Aleksieja Lidova.
}

korzystanie zasobów świeckiej sztuki w cerkwi jest oznaką sekularyzacji. Sztuka cerkiewna nie staje się świecką, ponieważ nabywa ona cech antropocentryzmu i jest ukierunkowana nie tylko na Transcendentne, ale również i na człowieka. Dlatego sztukę sakralną nowej epoki możemy rozpatrywać jako nowy rodzaj sztuki, definiując ją jako „nowa sakralność”. Należy zaznaczyć, że termin „nowa sakralność" istniał już wcześniej w muzykologii. Określano tym terminem opis twórczości o tematyce religijnej kompozytorów końca XIX i początku XX wieku. Rosyjska badaczka N. Wasiliewna, w swojej pracy „Tworczestwo Galiny Ustawolskoj w aspektie „nowoj sakralnosti” wyjaśnia genezę i zarys „nowej sakralności”, interpretując go na przykładzie twórczości kompozytorki (Vasil'eva, 2004, s. 24). Autorka zauważa częste odwoływanie się kompozytorów w czasach sowieckich do tematyki sakralnej. W 60-70 lata XX wieku, większość artystów traktowała muzykę sakralną jako coś wiecznego, ponadczasowego, etycznie stabilnego, jako symbol duchowości, a nie cerkwi. Pierwsza fala nowego ruchu religijnego przypada na 70-80 lata, kiedy to tematyka chrześcijańska była jeszcze zabroniona. Sakralny element, jakiego nie można było przekazywać oficjalnie poprzez słowo, był przekazywany poprzez świeckie gatunki muzyczne. Obdarowane religijnym znaczeniem zostało zilustrowane nową interpretacją w kategorii czasu i przestrzeni, dzięki czemu nasilały się medytacyjne cechy muzyki. W 80-90 latach zauważamy drugą falę religijnego ruchu, której cechą definiującą, były bezpośrednie aluzje religijne i zwrócenie się do religijnych tekstów. W samych utworach zmniejszała się semantyka samego komponentu muzycznego (Vasil'eva, 2004, s. 6-7).

We współczesnej muzykologii możemy zauważyć zróżnicowane podejścia do badania muzyki liturgicznej, utworów przeznaczonych do nabożeństw i muzyki, która tylko imituje zewnętrzną formę gatunku liturgicznego. Ten podział pozwoli rozgraniczyć dwa typy muzycznych utworów, napisanych w XX w., które odtwarzają zasady „,nowej sakralności”.

Pierwszy typ ukierunkowany jest na koncertowe wykonanie utworów, gdzie sakralność interpretuje się w kategorii artystyczno-estetycznej, a nie jako religijny fenomen pomimo głębokiej religijności ich autorów. Elementem charakterystycznym tych utworów jest wykorzystanie kanonicznych tekstów liturgicznych odwołujących się do średniowieczno-renesansowego albo barokowego stylu muzycznego. Najczęściej sam styl muzyczny wskazuje na charakterystyczny element „,nowej sakralności”.

Drugi typ utworów muzycznych przeznaczony jest dla liturgii jako dla sakralnego aktu nabożeństwa i jest jej integralną częścią. „Nowa sakralność” w tym przypadku polega na aktualizacji zasobów muzycznych, jakie kompozytor wykorzystuje w swojej twórczości do tego, aby muzyka sakralna odpowiadała potrzebom współczesności. Te utwory nie są przeznaczone do koncertowego wykonania. Wyznacznikiem sakralności dla nich jest funkcja liturgiczna, jeśli rzeczywiście ich głównym celem jest pomaganie w nawiązaniu komunikacji człowieka z Transcendentnym. 
Pomimo różnic w podejściu muzykologów co do określania kryteriów muzyki jako sakralnej i „,nowej sakralności" możemy odnaleźć kilka wspólnych kryteriów dla wszystkich badaczy. Po pierwsze, wszyscy zwracają uwagę na osobowość artysty i jego rozumienie kanonów cerkiewnych i jego stosunek do kanonicznego i niekanonicznego (indywidualnego) zastosowania $\mathrm{w}$ utworze muzycznym. Po drugie, stawiają wspólnie pytania co do różnić w rozumieniu sakralności i kanoniczności wschodnich i zachodnich tradycji chrześcijańskich. Po trzecie, kładą nacisk na autonomię słowa i muzyki w kompozycjach sakralnej treści. Po czwarte, bezpośrednio lub pośrednio zwracają uwagę na miejsce wykonania analizowanych dzieł, traktując sakralność jako indywidualne wyrażenie woli autora. Odpowiednio wszystkie komponenty powinny stać się zasadnicze przy rozwiązaniu pytania o specyfikę odtworzenia sakralności w utworach, które przeznaczone są do nabożeństw lub tylko naśladują formy liturgiczne. Wspólne stanowisko wskazuje, że między dwoma typami utworów (jako artefakty artystyczne) nie ma niezwyciężonej granicy i ten sam utwór może mieć sakralny wymiar w ramach działania synkretycznego a może być samowystarczalnym dziełem jaki zasobami muzyki odtwarza sakralny styl muzyki Renesansu i Średniowiecza.

Definicję „,nowa sakralność” używa się tradycyjnie dla charakterystyki muzyki z końca XX wieku. Możemy jednak zauważyć, że współczesny etap rozwoju muzyki cerkiewnej kontynuuje ten proces, który rozpoczął się właśnie pod koniec XX wieku. Źródła „nowej sakralności” muzyki XX wieku(liturgicznej i koncertowej) sięgają korzeniami doby Renesansu. Pomogło to odkryć nowy antropocentryczny wymiar muzyki cerkiewnej, który położył podwaliny pod interpretację liturgicznych gatunków muzycznych oraz koncertowych. Należy zaznaczyć, że termin „nowa sakralność" może być wykorzystywany nie tylko metaforycznie, ale także w sensie dosłownym, czyli, interpretując sakralność jako akt komunikacji z Bogiem podczas liturgii, w jakiej wzrasta waga indywidualności, przede wszystkim w jego wymiarze artystycznym.

Autonomia sakralna i artystyczna stopniowo podlega dyferencjacji na trzy równe formy: liturgiczny, paraliturgiczny i pozaliturgiczny. Dwie pierwsze są reprezentantami sakralności jako części synkretycznego i liturgicznego działania. Trzecia zaś symbolizuje związek sakralnego (cerkiewnego) ze świeckim (pozacerkiewnym). Muzyczny styl nie należy do podstawowych oznak ,nowej sakralności”, ponieważ jest on naturalnym czynnikiem ewolucji sztuki muzycznej. Potwierdzeniem tego jest muzyka różnych stylów, którą odnajdujemy w łacińskich liturgicznych utworach i tekstach z XVII-XIX, które przeznaczone są do nabożeństw. Przy tym muzyczny styl może służyć jako dodatkowy czynnik, szczególnie w tych przypadkach, kiedy w muzyce liturgicznej rozdzielają się pojęcia „stary kościelny styl” i „nowy kościelny styl”, gdzie nowy ma wyraźne oznaki antropocentrycznych tendencji.

Komponent językowy jest oznaką „nowej sakralności” muzyki liturgicznej nowych czasów. W średniowiecznej sztuce kanonicznej język liturgiczny był uważany za jeden z atrybutów sakralności, słusznie zauważając, że ma być podniosły i ma „unosić człowieka ponad ziemię”. Tłumaczenie oryginalnego tekstu liturgicznego na inny język nie do końca daje możliwość adekwatnie przyjąć zamierzoną intencję z religijnego punktu widzenia. Należy również zwrócić uwagę na to, że funkcjonalne rozumienie sakralności ukrywa w sobie pewne niebezpieczeństwo rozerwania między liturgiczno-obrzędową a estetyczną funkcją. W średniowieczu i później możemy zauważyć, że w utworach muzycznych aspekt sztuki zdecydowanie przemieniał nabożeństwo w duchowy koncert, czyli zamieniał go na sztukę, a nie na modlitwę. Dzisiaj możemy zauważyć przeciwstawne zjawisko, ponieważ komponent artystyczny przechodzi na drugi plan, często przez brak finansowych możliwości utrzymania wykwalifikowanego zespołu artystycznego. Między innymi przez ten element następuje obniżenie poziomu artystycznego muzyki liturgicznej.

Funkcjonalna interpretacja muzyki liturgicznej nowej ery pozwoliła przyciągać do cerkiewnych nabożeństw różne muzyczne gatunki, które w średniowieczu były uważane za nieliturgiczne. Wśród tych gatunków, które zajmują ważne miejsce $\mathrm{w}$ nabożeństwach $\mathrm{w}$ dzisiejszych czasach, jest tzw. duchowa pieśń. Jako składowa nabożeństw duchowa pieśń ostatecznie uformowała się we współczesności, dlatego jest wyraźnym przykładem „nowej sakralności”. Duchowa pieśń jest tym gatunkiem, gdzie najbardziej wyrażona jest szczególna cecha „nowej sakralności” i udziału wiernych w nabożeństwie. Autonomia sakralnego i artystycznego komponentu wyrażona $\mathrm{w}$ muzyce $\mathrm{i}$ tekstach pieśni duchowych jest ściśle powiązana z funkcjonalnym rozumieniem muzyki liturgicznej. W Cerkwi prawosławnej w Polsce pieśni duchowe oficjalnie funkcjonują jako paraliturgiczne. Jednak możemy zauważyć ich swoisty renesans w użyciu liturgicznym. W niektórych świątyniach używa się je w trakcie liturgii (w momencie przed przyjęciem przez wiernych eucharystii). Wschodniosłowiańska duchowa pieśń jest reprezentantem „nowej sakralności”. Z jednej strony jest częścią cerkiewnej kultury w jej świątynnym lub poza świątynnym wymiarze i służy jako komunikator między wiernym a Bogiem. Poza świątynne wykonanie duchowych pieśni odkrywa drogę do folkloryzowania ich, gdzie sakralność funkcjonuje w inny sposób niż w cerkiewnej kulturze. Cerkiewna sztuka, reprezentowana przez pieśni duchowe, która jest nakierunkowana na przeciętnego laika, zmienia swoje artystyczne priorytety i nabywa cech, które pozwalają patrzeć na nie w kontekście popularnej kultury. Przy tym sakralny wymiar cerkiewnych duchowych pieśni pozostaje niezmienny. Podsumowując, możemy stwierdzić, że wschodniosłowiańska duchowa pieśn formowała się w ogólnoeuropejskim paradygmacie „nowej sakralności”, którego głównymi cechami są uproszczenia językowe, czynny wzrost roli wiernych w liturgii, autonomia elementów sakralnych i artystycznych nabożeństwa oraz funkcjonalna interpretacja sakralności poprzez wydzielenie trzech równych sakralnych dziedzin: liturgicznej, paraliturgicznej i pozaliturgicznej. Sakralny komponent we wschodniosłowiańskim śpiewie 
duchowym jest przedstawiony we wszystkich poziomach: liturgicznym, paraliturgicznym, pozaliturgicznym.

„Nowa sakralność” jest otwartym systemem, który współdziała z różnymi warstwami kulturowymi, wśród których jest sakralny chrześcijański świat.

Średniowieczna sztuka cerkiewna jako środek religijnej komunikacji człowieka $\mathrm{z}$ Bogiem, dzięki środkom artystycznym, w symboliczny sposób odtwarzała nadprzyrodzony świat w sakralnej przestrzeni nabożeństwa. Antropocentryczny wymiar sztuki chrześcijańskiej, który rozpoczął się w baroku, aktualizował nową jakość muzyki religijnej. Charakteryzował się: dynamiką, jasnością, przejrzystością, monumentalnością, a jednocześnie prostotą. Te cechy nabierają szczególnego znaczenia $\mathrm{w}$ duchowej pieśni, która w pełni odpowiada pytaniom wierzącego nowej ery. Nie tylko jako indywidualna modlitewna pieśń, ale również jako składowa część nabożeństwa. Prostota, zrozumiałość tekstu, nieskomplikowane melodie, które skierowane były do wykonania przez chóry amatorskie dla wszystkich wiernych, stworzyły gatunek duchowej pieśni popularnej w całej Europie. Funkcjonalne rozumienie muzyki chrześcijańskiej poprzez dyferencjację trzech gatunków: liturgicznego, paraliturgicznego, pozaliturgicznego, miało swoje odzwierciedlenie w pieśni duchowej, jaka mogła wybrzmieć na liturgii lub na innych cerkiewnych nabożeństwach okolicznościowych. Stała się częścią sakralnej przestrzeni nabożeństwa i była wykonywana również jako indywidualna bądź wspólna, poza murami świątyni, której celem była sakralizacja dnia codziennego ludzkiego życia. Historia wschodniosłowiańskiej duchowej pieśni jest historią poszukiwania własnej drogi rozwoju. Gdzie próba zjedno- czenia dawnych tradycji, które sięgają swoimi korzeniami średniowiecza, pojednała się z radykalnym odnowieniem poetyckich i muzycznych form.

Podsumowując, możemy powiedzieć, że w dzisiejszych czasach (w epoce nowej sakralności) napotykamy nową falę twórczości duchowych pieśni i duchowej muzyki we wszystkich konfesjach chrześcijańskich. W odróżnieniu do poprzednich stuleci duchowa pieśn nie ma już polemicznego charakteru, a skierowana jest na formowanie chrześcijańskiego światopoglądu. Autorzy nowych duchowych pieśni w swoich utworach pragną wyrazić ducha czasu, przy tym zapisują wyznaniowe i narodowościowe tradycje jako punkty orientacyjne jej dalszego rozwoju. Odnosząc się do interpretacji sakralnych tekstów, kompozytorzy pragną podkreślić ich wszechstronność i starają się wywołać u słuchacza zaangażowanie w wieczne cenności duchowego życia. Rezultatem tego jest integracja duchowej muzyki minionej z nową warstwą prawosławnej kultury muzycznej. Współczesny rozwój duchowej pieśni nie jest nakierunkowany tylko na jej odrodzenie, ale również na nowe kierunki rozwoju. Przede wszystkim można zauważyć jej znaczną sekularyzację i asymilację ze świecką kulturą. Innowacją pieśni duchowych jest wykonanie ich $\mathrm{z}$ akompaniamentem. Pojawienie się takiego autorskiego kierunku pieśni duchowych jest uosobieniem syntezy cerkiewnej i świeckiej.

W dzisiejszej muzykologii, kulturologii i teologii pojawiają się próby określenia, w którym kierunku podążać ma współczesna muzyka liturgiczna. I niestety nie ma jednoznacznej opinii. Muzyka cerkiewna musi przede wszystkim wypełniać swoje podstawowe i najważniejsze zadanie, czyli pomoc wiernemu w rozmowie z Bogiem.

\section{Bibliografia}

Allemanov, D. (1911). Kurs istorii russkogo cerkovnogo peniâ. C. 1: Vvedenie v istorîu russkogo cerkovnogo peniâ (Penie $v$ Cerkvi vselenskoj). Moskva: Notopečatnâ P. Ûrgensona.

Gnatûk, O. (1994). Ukraïns'ka duhovna barokkova pìsnâ. Varšava - Kiïv: Pereval.

Gustova, L. A. (2011). Novyj podhod v izučenii sakral'noj pevčeskoj kul'tury pravoslavnoj tradicii: voprosy metodologii. Vescì Belaruskaj dzâržaŭnaj akadèmì muzyki. Vyp. 19. Mìnsk.

Losskij, N. O. (1931). Cennost' i bytie. Bog i Carstvo Božie kak osnova cennostej. Pariž.
Martynov, V. (1994). Istoriâ bogoslužebnogo peniâ: učebnoe posobie. Moskva.

Markova, E. N. (2000). Problemy muzykal'noj kul'turologii: navč. posibnik. Odessa.

Razumovskij, D. V. (1867). Cerkovnoe penie v Rossii. Moskva.

Vasil'eva, N. V. (2004). Tvorčestvo Galiny Ustvol's'koj v aspekte «novoj sakral'nosti». Nižnij Novgorod. Nižegorodskoj gosudarstvennoj konservatorii imeni M. I. Glinki.

Bolgars'ki, D. (2021). Spiv - ce proces oduhotvorennâ. № 24. [online] http://g-vik.narod.ru/2005/n25/05_25 s10.htm, [24.06.2021]. 